\title{
ОСОБЛИВОСТІ ОКИСНЮВАЛЬНОЇ МОДИФІКАЦІЇ ПРОТЕЇНІВ ПРИ КОМБІНОВАНІЙ ДІЇ ХАРЧОВИХ ДОБАВОК
}

Вступ. Скорочення тривалості життя населення України, різке зниження якості життя та індексу здоров'я нації при значному порушенні харчового статусу зумовлюють необхідність порушення питань щодо якості харчової продукції, в тому числі й неконтрольованого використання харчових добавок, тому дане дослідження $є$ актуальним.

Мета дослідження - оцінити показники окиснювальної модифрікації протеїнів у тканинах організму щурів при застосуванні розчинів к-карагінану, натрію глутамату та їх комбінованій дії.

Методи дослідження. Дослідження проведено на 48 білих нелінійних щурах-самцях, яких поділили на 4 групи: 1-ша - контроль (інтактні тварини); 2-га - тварини, яким внутрішньошлунково вводили к-карагінан у дозі 40 мг/ке протягом 1 місячя; 3-тя - тварини, яким внутрішньошлунково вводили натрію глутамат у дозі 50 мг/ке; 4-та - тварини, яким внутрішньошлунково вводили к-карагінан і натрію глутамат у вищевказаних дозах. Для оцінки спонтанної окиснювальної модифрікації протеїнів (ОМП) спектрофротометрично в ультрафріолетовій частині спектра на довжині хвилі 370 нм визначали кетондинітрофренілгідразони нейтрального характеру (КДНФГ) та в ділянці видимого світла 430 нм - альдегіддинітрофренілгідразони основного характеру (АДНФГ). 3 метою оцінки стимульованої ОМП попередньо додавали до до-

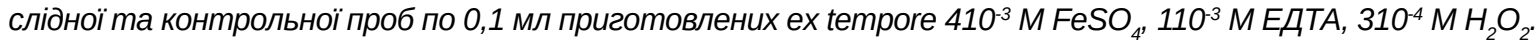

Результати й обговорення. У сироватці крові частка первинних (АДНФГ) і вторинних (КДНФГ) маркерів дослідних груп практично не відрізнялася від співвідношення в контрольній групі. У тканинах легень при введенні експериментальним тваринам натрій глутамату змінювалося співвідношення АДНФГ до КДНФГ у бік збільшення частки вторинних маркерів оксидативного стресу, тоді як в інших дослідних групах їх співвідношення практично не відрізнялося від контролю. У тканинах печінки частка первинних $i$ вторинних маркерів дослідних груп практично не відрізнялася від співвідношення в контрольній групі. Аналіз співвідношення первинних і вторинних маркерів ОМП вказує на збільшення частки маркерів пізньої деструкції в тканинах легень при застосуванні натрій глутамату. Менша частка вторинних маркерів у сироватці крові при введенні к-карагінану, стосовно групи тварин, яким вводили натрій глутамат, може свідчити про швидшу утилізацію змінених протеїнів, так званий вторинний антиоксидантний ефект.

Висновок. За умови комбінованої дії розчинів к-карагінану і натрій глутамату вірогідно підвищується спонтанна окиснювальна модифікація протеїнів стосовно контролю та окремої дії харчових добавок, що супроводжується виснаженням резервно-адаптаційного потенціалу в крові, легенях і печінці, відповідно, на 33,4, 32,9 ma 24,0\%. ефект.

КЛЮчОВІ СЛОВА: харчові добавки; окиснювальна модифікація протеїнів; кров; печінка; легені;

ВСТУП. Особливості сучасного харчування тісно пов'язані з використанням широкого спектра харчових добавок - речовин, які додають в їжу з певною технологічною метою, наприклад, для запобігання псуванню, збереження структури їжі або поліпшення її органолептичних властивостей [1]. В Європейському Союзі (ЄС) правила застосування харчових добавок встановлені Регламентом Європейського парламенту і Ради № 1333/2008 [2]. В Україні до початку 90-х років XX ст. використання харчових добавок було (c) П. І. Бучко, М. І. Марущак, 2020. обмеженим порівняно із зарубіжними країнами, зокрема, до 1994 р. дозволяли застосовувати лише 194 харчових добавки, а згідно з Постановою Кабінету Міністрів у 2000 р. - 221 [3]. У Законі України від 03.02.2011 р. № 2973-VI “Про безпечність та якість харчових продуктів" зазначено, що харчова добавка дозволяється до використання за умов, якщо вона не становить небезпеки для здоров'я споживача на рівні застосування, на якому пропонується, що може бути встановлено на підставі доступних наукових доказів [4]. 3 огляду на затверджений Регламент 
ЄС № 1331/2008, наказом Міністерства охорони здоров'я України від 20.03.2013 р. № 218 було передбачено затвердження порядку державної реєстрації харчових добавок, ароматизаторів та ензимів, а також санітарні правила і норми щодо їх застосування, в тому числі їх переліку, дозволеного для використання в харчових продуктах [5]. 3 метою приведення процедур реєстрації харчових добавок у відповідність із законодавством ЄС у 2018 р. у МОЗ розробили проект наказу про затвердження порядку проведення державної реєстрації харчових добавок, ведення реєстру та надання інфоормації з нього, проте нормативно-правового акта так і не прийняли. В $€ С$ постійно спостерігають за безпекою використання харчових продуктів, враховуючи не тільки нову наукову інформацію, але й потенційні зміни у споживанні харчових добавок населенням [6]. Скорочення тривалості життя населення України, різке зниження якості життя та індексу здоров'я нації при значному порушенні харчового статусу зумовлюють необхідність порушення питань щодо якості харчової продукції, в тому числі й неконтрольованого використання харчових добавок [7], тому дане дослідження $є$ актуальним.

Мета дослідження - оцінити показники окиснювальної модисрікації протеїнів у тканинах організму щурів при застосуванні розчинів к-карагінану, натрію глутамату та їх комбінованій дії.

МЕТОДИ ДОСЛІДЖЕННЯ. Дослідження проведено на 48 білих нелінійних щурах-самцях, яких утримували на стандартному раціоні віварію Тернопільського національного медичного університету імені І. Я. Горбачевського МОЗ України. Під час роботи дотримувалися принципів Європейської конвенції про захист хребетних тварин, що використовуються для дослідних та інших наукових цілей. Піддослідних тварин поділили на 4 групи: 1-ша - контроль (інтактні тварини) (n=12); 2-га - тварини, яким внутрішньошлунково вводили к-карагінан у дозі $40 \mathrm{mr} / к г$, розчинений у 0,5 мл дистильованої води кімнатної температури, протягом 1 місяця $(\mathrm{n}=12)[8,9]$; 3-тя - тварини, яким внутрішньошлунково вводили натрію глутамат у дозі 50 мг/кг, розчинений у 0,5 мл дистильованої води кімнатної температури, протягом 1 місяця ( $\mathrm{n=12)}$ [10]; 4-та - тварини, яким внутрішньошлунково вводили к-карагінан і натрію глутамат у вищевказаних дозах $(n=12)$.

Для приготування $10 \%$ гомогенату відібрані відразу ж після евтаназії зразки легень і печінки охолоджували у фрізіологічному розчині до 1-3 ${ }^{\circ} \mathrm{C}$, підсушували фрільтрувальним папером, потім подрібнювали ножицями та гомогенізували в 0,05 M трис-HCl буфрері $(\mathrm{pH} 7,4)$ за допомогою магнітного гомогенізатора SilentCruser S (Heidolph, Germany) у співвідношенні 1:9 (маса тканини:об'єм буфрера). Отриманий гомогенат центрифугували протягом 30 хв при 3000 об./хв на центрисрузі з охолодженням Hermle Z 32 HK. Для досліджень використовували надосадову рідину [11].

Для оцінки спонтанної окиснювальної модифрікації протеїнів (ОМП) використовували методику визначення рівня карбонільних похідних за R. L. Levine в модифрікації $€$. $€$. Дубініної [12]. Метод оцінки ОМП базується на реакції взаємодії карбонільних похідних окиснених амінокислотних залишків протеїнів з 2,4-динітрофенілгідразином з утворенням 2,4-динітрофенілгідразонів, які реєструють за допомогою спектрофротометра в ультрасріолетовій частині спектра на довжині хвилі 370 нм (кетондинітросренілгідразони нейтрального характеру - КДНФГ) та в ділянці видимого світла 430 нм (альдегіддинітрофенілгідразони основного характеру - АДНФГ). Отримані результати виражали в ум. од./г протеїну. Вміст протеїну в тканинах організму та лізаті еритроцитів визначали за методом Лоурі [13]. Для оцінки стимульованої ОМП карбонільні протеїни визначали аналогічним чином, як і спонтанної, з попереднім додаванням до дослідної та контрольної проб по 0,1 мл приготовлених ex tempore $410^{-3} \mathrm{M} \mathrm{FeSO}_{4}, 110^{-3} \mathrm{M}$ ЕДТА, $310^{-4} \mathrm{M}$ $\mathrm{H}_{2} \mathrm{O}_{2}$, при цьому взаємодія $\mathrm{Fe}^{2+} 3 \mathrm{H}_{2} \mathrm{O}_{2}$ сприяла подальшому утворенню гідроксильного радикала $\left(\mathrm{OH}^{-}\right)$за реакцією Фентона.

Оцінку спонтанної і стимульованої ОМП на різних довжинах хвиль поглинання інтерпретували окремо, а також шляхом співвідношення результатів вимірювання продуктів спонтанного до стимульованого окиснення, що характеризує резервно-адаптаційний потенціал (РАП) [14].

Статистичну обробку результатів здійснювали з використанням комп'ютерних програм STATISTICA 7.0 та Excel 2007. Вибір методу статистичного дослідження базувався на правильності розподілу досліджуваних ознак. Зважаючи на неправильний розподіл кількісних характеристик, їх описову статистику здійснювали у вигляді reported as medians and interquartile range (IQ, percentile 25 and percentile 75). Подальше попарне порівнювання груп проводили з використанням U-критерію Манна - Уїтні при оцінюванні рівня статистичної значущості р<0,05.

РЕЗУЛЬТАТИ Й ОБГОВОРЕННЯ. ОДНИМ 3 надійних індикаторів оксидативного стресу й ушкодження тканин за умови активації процесів вільнорадикального окиснення є ОМП, у результаті якої змінюються структура, срізико-хімічні та 
біологічні властивості протеїнової молекули, що призводить до інактивації великої групи ензимів [15]. Установлено, що в сироватці крові рівень АДНФГ зростав: у 1-й групі - на 24,10\%, у 2-й і 3-й - відповідно, на 40,96 та 102,41 \% стосовно контролю. При цьому досліджуваний показник був найвищим у 3-й групі, найнижчим - у 1-й. У тканинах легень рівень АДНФГ збільшувався: в 1-й групі - на 12,93 \%, у 2-й і 3-й - відповідно, на 59,48 та 81,90 \% щодо контролю. Порівнюючи дослідні групи між собою, встановили вірогідно вище значення досліджуваного показника у 3-й групі, найнижче - в 1-й стосовно інших груп. У печінці рівень АДНФГ зростав: у 1-й групі - на 31,37 \%, у 2-й і 3-й - відповідно, на 47,06 \% та 70,59 \% проти контрольних значень. Варто зазначити, що при комбінованому використанні к-карагінану і натрій глутамату досліджуваний показник був найвищим (табл. 1).
У сироватці крові рівень КДНФГ зростав: у 1-й групі - на 29,28 \%, у 2-й і 3-й - відповідно, на 22,10 та 93,92 \% стосовно контролю. При цьому досліджуваний показник був найвищим у 3-й групі. У тканинах легень рівень КДНФГ збільшувався: в 1-й групі - на 9,35 \%, у 2-й і 3-й - відповідно, на 36,69 та 93,53 \% щодо контролю. Порівнюючи дослідні групи між собою, встановили вірогідно вище значення досліджуваного показника у 3-й групі, найнижче - в 1-й стосовно інших груп. У печінці рівень КДНФГ зростав: у 1-й групі - на 20,83 \%, у 2-й і 3-й - відповідно, на 47,92 та 72,92 \% проти контрольних значень. Варто зазначити, що при комбінованому використанні к-карагінану і натрій глутамату досліджуваний показник був найвищим (табл. 2).

3 метою оцінки первинних (АДНФГ) і вторинних (КДНФГ) маркерів оксидативного стресу та функціонального стану клітини в процесі нако-

Таблиця 1 - Показники спонтанної окиснювальної модифрікації протеїнів у сироватці крові щурів за рівнем альдегіддинітрофенілгідразонів основного характеру (ум. од./г протеїну) при комбінованій дії харчових добавок

\begin{tabular}{||l|c|c|c||}
\hline \multicolumn{1}{|c|}{ Група тварин } & Кров & Легені & Печінка \\
\hline Контроль & 0,42 & 0,58 & 0,26 \\
& $(0,38 ; 0,48)$ & $(0,54 ; 0,63)$ & $(0,24 ; 0,28)$ \\
\hline 1-ша (к-карагінан) & 0,52 & 0,66 & 0,34 \\
& $(0,51 ; 0,54)$ & $(0,64 ; 0,68)$ & $(0,31 ; 0,36)$ \\
& $p_{1}<0,05$ & $p_{1}<0,05$ & $p_{1}<0,05$ \\
& $p_{2}<0,05$ & $p_{2}<0,05$ & $p_{2}>0,05$ \\
\hline 2-га (натрію глутамат) & 0,59 & 0,93 & 0,38 \\
& $(0,58 ; 0,61)$ & $(0,85 ; 0,95)$ & $(0,34 ; 0,40)$ \\
& $p_{1}<0,05$ & $p_{1}<0,05$ & $p_{1}<0,05$ \\
3-тя (к-карагінан+натрію & $p_{3}<0,05$ & $p_{3}<0,05$ & $p_{3}<0,05$ \\
глутамат) & 0,84 & 1,06 & 0,44 \\
& $(0,78 ; 0,87)$ & $(0,98 ; 1,09)$ & $(0,41 ; 0,47)$ \\
\hline
\end{tabular}

Примітка. Тут і в таблицях 2-4: $p_{1}$ - зміни вірогідні відносно показників контрольних тварин; p $_{2}$ - вірогідність змін між 1-ю і 2-ю групами; $p_{3}$ - вірогідність змін між 2-ю і 3-ю групами; $p_{4}$ - вірогідність змін між 1-ю і 3-ю групами.

Таблиця 2 - Показники спонтанної окиснювальної модифікації протеїнів у сироватці крові щурів за рівнем кетондинітрофенілгідразонів нейтрального характеру (ум. од./г протеїну) при комбінованій дії харчових добавок

\begin{tabular}{|l|c|c|c||}
\hline \multicolumn{1}{|c|}{ Група тварин } & Кров & Легені & Печінка \\
\hline Контроль & 0,91 & 1,39 & 0,48 \\
& $(0,88 ; 0,95)$ & $(1,34 ; 1,43)$ & $(0,45 ; 0,51)$ \\
\hline 1-ша (к-карагінан) & 1,17 & 1,52 & 0,58 \\
& $(1,11 ; 1,21)$ & $(1,48 ; 1,57)$ & $(0,55 ; 0,61)$ \\
& $p_{1}<0,05$ & $p_{1}<0,05$ & $p_{1}<0,05$ \\
& $p_{2}>0,05$ & $p_{2}<0,05$ & $p_{2}<0,05$ \\
\hline 2-га (натрію глутамат) & 1,11 & 1,90 & 0,71 \\
& $(1,08 ; 1,15)$ & $(1,87 ; 1,95)$ & $(0,68 ; 0,75)$ \\
& $p_{1}<0,05$ & $p_{1}<0,05$ & $p_{1}<0,05$ \\
& $p_{3}<0,05$ & $p_{3}<0,05$ & $p_{3}<0,05$ \\
\hline 3-тя (к-карагінан+натрію & 1,76 & 2,69 & 0,83 \\
глутамат) & $(1,69 ; 1,78)$ & $(2,60 ; 2,72)$ & $(0,76 ; 0,93)$ \\
& $p_{1}<0,05$ & $p_{1}<0,05$ & $p_{1}<0,05$ \\
& $p_{4}<0,05$ & $p_{4}<0,05$ & $p_{4}<0,05$ \\
\hline \hline
\end{tabular}


пичення окиснених протеїнів було проаналізовано окремо частку альдегідів і кетонів у сумарній ОМП [16]. Встановлено, що у сироватці крові частка первинних і вторинних маркерів дослідних груп практично не відрізнялася від співвідношення в контрольній групі (рис. 1). Варто зазначити, що значення частки вторинних маркерів було більшим у 2-й групі стосовно 1-ї.

У тканинах легень при введенні експериментальним тваринам натрій глутамату змінювалося співвідношення АДНФГ до КДНФГ у бік зростання частки вторинних маркерів оксидативного стресу, тоді як в інших дослідних групах їх співвідношення практично не відрізнялося від контролю (рис. 2).

У тканинах печінки частка первинних і вторинних маркерів дослідних груп практично не відрізнялася від співвідношення в контрольній групі (рис. 3).
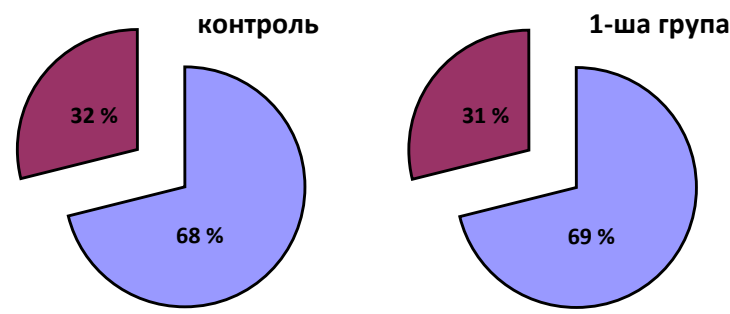

口омП 430 (первинні маркери)
Аналіз співвідношення первинних і вторинних маркерів окиснювальної модифрікації протеїнів вказує на зростання маркерів пізньої деструкції в тканинах легень при застосуванні натрій глутамату. Нижча частка вторинних маркерів у сироватці крові при введенні к-карагінану, стосовно групи тварин, яким вводили натрій глутамат, може свідчити про швидшу утилізацію змінених протеїнів, так званий вторинний антиоксидантний есрект.

Стимульоване окиснення на даний час розглядають як посттранскрипційну окиснювальну модифрікацію протеїнів [17], що виявляє зміни амінокислот, які входять до складу поліпептидного ланцюга, та модифрікації, пов'язані 3 консрормацією молекули і станом протеїнового оточення [18]. Необхідність вивчення спонтанної та індукованої іонами металів ОМП також дозволяє провести непряме оцінювання антиокси-
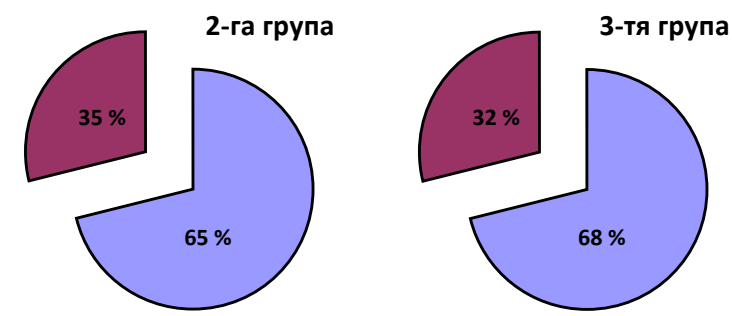

口омП 370 (вторинні маркери)

Рис. 1. Частка первинних і вторинних маркерів окиснювальної модифікації протеїнів у сироватці крові щурів при комбінованій дії харчових добавок.
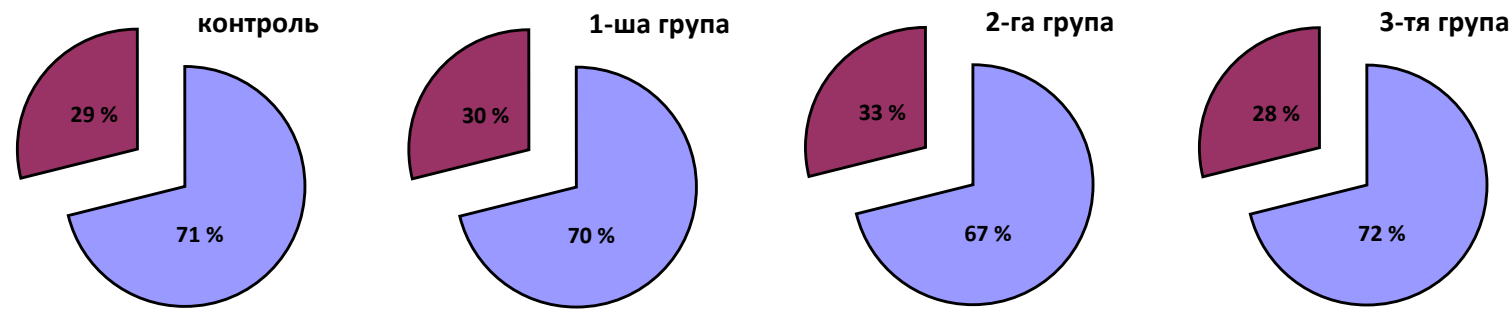

口ОМП 430 (первинні маркери)

口оМП 370 (вторинні маркери)

Рис. 2. Частка первинних і вторинних маркерів окиснювальної модисрікації протеїнів у легенях щурів при комбінованій дії харчових добавок.
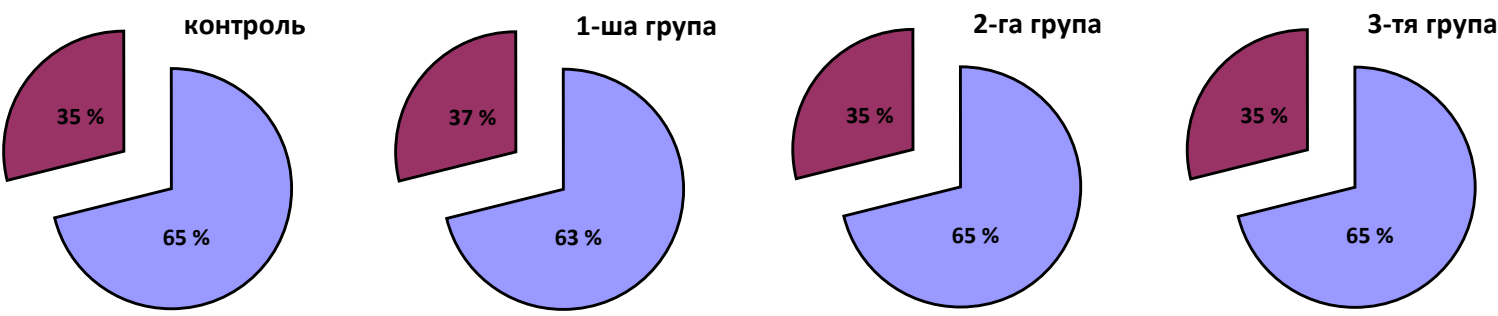

$\square \mathrm{OM}_{430}$ (первинні маркери)

口омП ${ }_{370}$ (вторинні маркери)

Рис. 3. Частка первинних і вторинних маркерів окиснювальної модифрікації протеїнів у печінці щурів при комбінованій дії харчових добавок. 
дантних можливостей протеїнів за допомогою РАП [19].

При оцінюванні стимульованої ОМП встановлено вірогідно вищі значення АДНФГ у всіх дослідних групах у сироватці крові, легенях і печінці відносно контролю. При цьому в сироватці крові рівень АДНФГ у 3-й групі вірогідно був вищим від даних 1-ї групи та практично не відрізнявся в 2-й і 3-й групах; у легенях у 1-й та 3-й групах він статистично значимо не відрізнявся, проте був більшим від даних 2-ї групи, тоді як у печінці найвище значення досліджуваного показника зареєстровано в 1-й групі (табл. 3).

У сироватці крові, легенях та печінці рівень КДНФГ був вірогідно більшим у всіх дослідних групах стосовно контролю. Порівнюючи дослідні групи між собою, встановили вірогідно вище значення досліджуваного показника в 1-й групі щодо практично однакових значень у 2-й і 3-й групах (табл. 4).
Для оцінки РАП у тканинах організму щурів визначали частку спонтанної ОМП у стимульованій ОМП, яку брали за 100 \%. Установлено, що в контрольній групі частка спонтанної ОМП:РАП становила у сироватці крові 54,7:45,3 (\%), у легенях - 56,5:43,5 (\%) та в печінці-50,5:49,5 (\%). За умови введення тваринам $1,0 \%$ розчину к-карагінану резервно-адаптаційний потенціал зростав у легенях (на 4,7 \%) і печінці (на 19,6 \%) стосовно контролю. При введенні щурам натрій глутамату він знижувався в усіх досліджуваних тканинах щодо контролю, зокрема, в сироватці крові - на 4,8 \%, у легенях - на 17,4 \% і в печінці-на 15,2\%. Комбінована дія харчових добавок зумовлювала максимальне виснаження РАП у всіх досліджуваних тканинах: у сироватці крові на $33,4 \%$, у легенях - на 32,9 \% і в печінці - на 24,0 \% (рис. 4). Отже, за умови комбінованої дії харчових добавок підвищення окиснювального стресу супроводжується виснаженням резерв-

Таблиця 3 - Показники стимульованої окиснювальної модифрікації протеїнів у сироватці крові щурів за рівнем альдегіддинітрофенілгідразонів основного характеру (ум. од./г протеїну) при комбінованій дії харчових добавок

\begin{tabular}{||l|c|c|c||}
\hline \multicolumn{1}{|c|}{ Група тварин } & Кров & Легені & Печінка \\
\hline Контроль & 0,94 & 1,15 & 0,69 \\
& $(0,89 ; 0,95)$ & $(1,09 ; 1,19)$ & $(0,66 ; 0,71)$ \\
\hline 1-ша (к-карагінан) & 1,02 & 1,29 & 1,08 \\
& $(0,96 ; 1,05)$ & $(1,24 ; 1,31)$ & $(1,00 ; 1,12)$ \\
& $p_{1}<0,05$ & $p_{1}<0,05$ & $p_{1}<0,05$ \\
& $p_{2}<0,05$ & $p_{2}<0,05$ & $p_{2}<0,05$ \\
\hline 2-га (натрію глутамат) & 1,16 & 1,22 & 0,78 \\
& $(1,14 ; 1,25)$ & $(1,18 ; 1,27)$ & $(0,75 ; 0,81)$ \\
& $p_{1}<0,05$ & $p_{1}<0,05$ & $p_{1}<0,05$ \\
& $p_{3}>0,05$ & $p_{3}<0,05$ & $p_{3}>0,05$ \\
\hline 3-тя (к-карагінан+натрію & 1,19 & 1,29 & 0,77 \\
глутамат) & $(0,99 ; 1,09)$ & $(1,24 ; 1,31)$ & $(0,75 ; 0,78)$ \\
& $p_{1}<0,05$ & $p_{1}<0,05$ & $p_{1}<0,05$ \\
& $p_{4}>0,05$ & $p_{4}>0,05$ & $p_{4}<0,05$ \\
\hline
\end{tabular}

Таблиця 4 - Показники стимульованої окиснювальної модифрікації протеїнів у сироватці крові щурів за рівнем кетондинітрофенілгідразонів нейтрального характеру (ум. од./г протеїну) при комбінованій дії харчових добавок

\begin{tabular}{||l|c|c|c||}
\hline \multicolumn{1}{|c|}{ Група тварин } & Кров & Легені & Печінка \\
\hline Контроль & 1,52 & 2,37 & 0,78 \\
& $(1,48 ; 1,58)$ & $(2,24 ; 2,44)$ & $(0,75 ; 0,86)$ \\
\hline 1-ша (к-карагінан) & 1,93 & 2,88 & 1,37 \\
& $(1,88 ; 1,97)$ & $(2,80 ; 2,92)$ & $(1,33 ; 1,42)$ \\
& $\mathrm{p}_{1}<0,05$ & $\mathrm{p}_{1}<0,05$ & $\mathrm{p}_{1}<0,05$ \\
& $\mathrm{p}_{2}<0,05$ & $\mathrm{p}_{2}<0,05$ & $\mathrm{p}_{2}>0,05$ \\
\hline 2-га (натрію глутамат) & 1,70 & 2,57 & 0,89 \\
& $(1,67 ; 1,75)$ & $(2,54 ; 2,59)$ & $(0,85 ; 0,95)$ \\
& $\mathrm{p}_{1}<0,05$ & $\mathrm{p}_{1}<0,05$ & $\mathrm{p}_{1}<0,05$ \\
& $\mathrm{p}_{3}>0,05$ & $\mathrm{p}_{3}>0,05$ & $\mathrm{p}_{3}>0,05$ \\
\hline 3-тя (к-карагінан+натрію & 1,73 & 2,62 & 0,91 \\
глутамат) & $(1,67 ; 1,75)$ & $(2,58 ; 2,65)$ & $(0,88 ; 0,94)$ \\
& $\mathrm{p}_{1}<0,05$ & $\mathrm{p}_{1}<0,05$ & $\mathrm{p}_{1}<0,05$ \\
& $\mathrm{p}_{4}<0,05$ & $\mathrm{p}_{4}<0,05$ & $\mathrm{p}_{4}<0,05$ \\
\hline
\end{tabular}


1-ша група

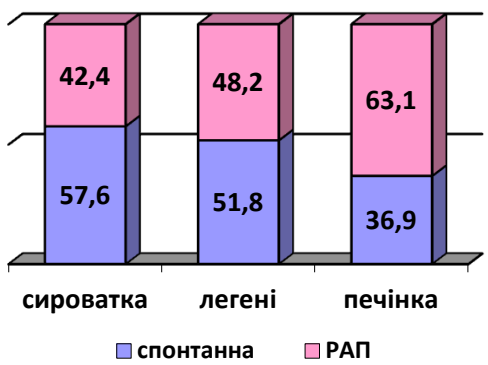

2-га група

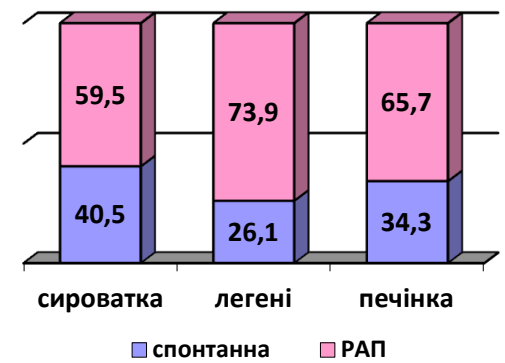

3-тя група

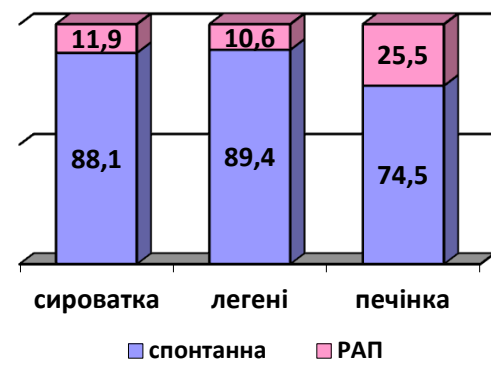

Рис. 4. Оцінка резервно-адаптаційного потенціалу в тканинах організму щурів при комбінованій дії харчових добавок (\%).

но-адаптаційного потенціалу в крові, легенях і печінці.

За даними інших авторів, споживання щурами 1,0 \% розчину к-карагінану зумовлювало зростання спонтанної ОМП, при цьому вони також припускали виснаження резервно-адаптаційних можливостей організму тварин [20, 21]. Проте дослідження спонтанної і стимульованої ОМП, яке ми провели, дозволяє об'єктивніше оцінити РАП. Дослідження вченими особливостей ОМП при дії натрій глутамату підтверджує наші дані щодо більш вираженого зростання ОМП на різних довжинах хвиль з розвитком карбонільного стресу [22]. Виявлене посилення окиснювальної деструкції протеїнових молекул 3 виснаженням резервно-адаптаційного потен- ціалу в крові, легенях і печінці щурів за умови комбінованої дії харчових добавок свідчить про порушення механізмів регуляції ензимних систем, які забезпечують клітинний гомеостаз, оскільки відомо, що при оксидативному стресі активні форми оксигену впливають передусім на протеїни плазматичних мембран, що призводить до вираженої гістодеструкції [23, 24].

ВИСНОВОК. За умови комбінованої дії розчинів к-карагінану і натрій глутамату вірогідно підвищується спонтанна окиснювальна модифікація протеїнів стосовно контролю та окремої дії харчових добавок, що супроводжується виснаженням резервно-адаптаційного потенціалу в крові, легенях і печінці, відповідно, на 33,4, 32,9 та $24,0 \%$.

\section{СПИСОК ЛІТЕРАТУРИ}

1. Kukk M. Risk assessment related to food additives and food processing-derived chemical contaminants exposure for the Portuguese population / M. Kukk, D. Torres // EFSA Journal. - 2020. - 18. - 10 p.

2. Regulation (EC) No $1333 / 2008$ of the European Parliament and of the Council of 16 December 2008 on food additives / European Union. - Strasburg: 2008.

3. Смоляр В. І. Токсичні ефекти харчових добавок / В. І. Смоляр // Проблеми харчування. - 2005. - № 1. C. 5-15.

4. https://zakononline.com.ua/documents/show/ $198223 \quad 570498$

5. Про Національний план дій на 2013 рік щодо впровадження Програми економічних реформ на 2010-2014 роки "Заможне суспільство, конкурентоспроможна економіка, ефективна держава" : Указ Президента України від 12.03.2013 р. № 128/2013 / Верховна Рада України.

6. Commission Regulation (EU) No 257/2010 of 25 March 2010 setting up a programme for the re-evaluation of approved food additives in accordance with Regulation (EC) No 1333/2008 of the European Parliament and of the Council on food additives / European Union. - Strasburg: 2010.
7. Кошкалда І. В. Актуальні питання продовольчого забезпечення / I. В. Кошкалда // Вісн. Сумського національного аграрного університету. Серія "Економіка і менеджмент”. - 2017. - № 4 (71). - С. 207-212.

8. Пат. 97322 Україна, МПK G09B 23/28. Спосіб моделювання хронічного гастроентероколіту / Іваненко Т. О., Коробчанський В. О., Губіна-Вакулик Г. І., Горбач Т. В., Колоусова Н. Г. - № a201014510 ; заявл. 06.12.2010 ; опубл. 25.01.2012, Бюл. № 2.

9. Moyana T. N. Carrageenan-induced intestinal injury in the rat-a model for inflammatory bowel disease / T. N. Moyana, J. M. Lalonde // Ann. Clin. Lab. Sci. 1990. - 20, 6. - P. 420-426.

10. Влияние глипролинов на структурно-функциональное состояние слизистой оболочки желудка и массу тела крыс в условиях длительного введения глутамата натрия / Т. М. Фалалеева, Г. Е. Самонина, Т. В. Береговая [и др.] // Фізика живого. - 2010. - 18, № 1. - С. 154-159.

11. Досвядчинська М. Р. Пероксидне окиснення ліпідів та активність антиоксидантних ензимів у клітинах легень щурів за щодобового введення афлатоксину В1 / М. Р. Досвядчинська, Г. Л. Антоняк // Біологія тварин. - 2012. - 14, № 1-2. - С. 108-112. 
12. Окислительная модификация белков плазмь крови больных психическими расстройствами (депрессия, деперсонализация) / Е. Е. Дубинина, М. Г. Морозова, Н. В. Леонова [и др.] // Вопр. мед. химии. - 2000. - 46, № 4. - С. 398-409.

13. Protein measurement with the Folin phenol reagent / O. H. Lowery, N. I. Rosebroughh, A. L. Farr R. I. Randall // J. Biol. Chem. - 1951 - 193 (1) . - P. 265275.

14. Jones L. A. Spectrophotometric studies of some 2,4-dinitrophenylhydrazones / L. A. Jones, J. C. Holmes, R. B. Seligman // Analytical Chemistry. - 1956. - 28 No. 2. - P. 191-198.

15. Шевелькова А. А. Окислительная модисрикация белков и содержание тиолов в крови при сризиологически протекающей беременности / А. А. Шевелькова, А. В. Вьюшина // Журн. акушерства и женских болезней. - 2012. - 61, № 4. - С. 109-112.

16. Губский Ю. И. Токсикологические последствия окислительной модисрикации белков при различных патологических состояниях (обзор литературы) Ю. И. Губский // Современные проблемы токсикологии. - 2005. - 8, № 3. - С. 20-27.

17. Дубинина Е. Е. Продукты метаболизма кислорода в функциональной активности клеток (жизнь и смерть, созидание и разрушение). Физиологические и клинико-биохимические аспекты /Е. Е. Дубинина. СПб. : Медицинская пресса, 2006. - С. 400.

18. Ведунова М. В. Влияние низких терапевтических доз озона на уровень окислительной модисикации белков / М. В. Ведунова, А. И. Сазанов, К. Н. Контор- щикова // Вестн. Нижегородского университета им. Н. И. Лобачевского. - 2010. - № 2. - С. 504-507.

19. Ergin, V. Carbonyl stress in aging process: Role of vitamins and phytochemicals as redox regulators I V. Ergin, R. E. Hariry, C. Karasu // Aging and Disease. 2013. - 4, No. 5. - P. 279-294.

20. Мялюк О. П. Стан вільнорадикального окиснення у тканинах печінки експериментальних щурів при аліментарному ожирінні / О. П. Мялюк // Вісн. проблем біології і медицини. - 2015. - Вип. 4 (1). C. $120-123$.

21. Krynytska I. The indices of endogenous intoxication in rats with carrageenan solution consumption / I. Krynytska, M. Marushchak, O. Svan [et al.] // Georgian Medical News. - 279. - P. 196-200.

22. Krynytska I. Gender-specific differences of oxidative processes in the population of circulating neutrophils of rats in a setting of prolonged administration of monosodium glutamate / Inna Krynytska, Mariya Marushchak, Anastasiia Rutska// Romanian Journal of Diabetes Nutrition and Metabolic Diseases. - 2019. - 26, No 2. P. 119-127.

23. Зинь А. Окисна модисрікація білків у зародках в'юна MISGURNUS FOSSILIS L. упродовж ембріогенезу за дії гіпохлориту натрію / А. Зинь, Н. Головчак, Д. Санагурський // Вісн. Львівського університету. Серія біологічна. - 2013. - Вип. 61. - С. 11-19.

24. Марущак М. І. Роль активних фрорм кисню у розвитку і прогресуванні гострого ураження легень в експерименті / М. І. Марущак // Мед. хімія. -2012. -14, № 1 (50). - C. 104-108.

\section{REFERENCES}

1. Kukk, M., \& Torres, D. (2020). Risk assessment related to food additives and food processing-derived chemical contaminants exposure for the Portuguese population. University of Porto, Faculty of Nutrition and Food Sciences. EFSA Journal, 18 (1), 10.

2. (2008). Regulation (EC) No $1333 / 2008$ of the European Parliament and of the Council of 16 December 2008 on food additives. European Union.

3. Smolyar, V.I. (2005). Toksychni efekty kharchovykh dobavok [Toxic effects of food additives]. Problemy kharchuvannia - Nutrition Problems, 1, 5-15 [in Ukrainian].

4. https://zakononline.com.ua/documents/show/ 198223570498

5. Pro Natsionalnyi plan dii na 2013 rik shchodo vprovadzhennia Prohramy ekonomichnykh reform na 2010-2014 roky "Zamozhne suspilstvo konkurentnospromozhna ekonomika, efektyvna derzhava" [On the National Action Plan for 2013 on the implementation of the Program of economic reforms for 2010-2014 "Wealthy society, competitive economy, efficient state"]. Ukaz Prezydenta Ukrainy - Decree of the President of Ukraine, March 12, 2013 No. 128 [in Ukrainian].

6. (2010). Commission Regulation (EU) No 257/2010 of 25.03.2010 setting up a programme for the re-evaluation of approved food additives in accordance with Regulation (EC) No 1333/2008 of the European Parliament and of the Council on food additives. European Union.

7. Koshkalda, I.V. (2017). Aktualni pytannia prodovolchoho zabezpechennia [Current issues of food supply]. Visnyk Sumskoho natsionalnoho ahrarnoho universytetu. Seriia "Ekonomika i menedzhment" - Bulletin of Sumy National Agrarian University. Series "Economics and Management", 4 (71), 207-212 [in Ukrainian].

8. Ivanenko, T.O., Korobchanskyy, V.O., HubinaVakulyk, H.I., Horbach, T.V., \& Kolusova, N.H. Sposib modeliuvania khronichnoho hastroenterokolitu [Method of modeling chronic gastroenterocolitis]. Pat. 97322 Ukraine, MPK G09B 23/28. № a201014510, stat. 06.12.2010, publish. 25.01.2012, 2 [in Ukrainain].

9. Moyana, T.N., \& Lalonde, J.M. (1990). Carrageenan-induced intestinal injury in the rat - a model for inflammatory bowel disease. Ann. Clin. Lab. Sci., 20, 6, 420-426.

10. Falaleeva, T.M., Samonina, H.E., \& Berehovaya, T.V. (2010). Vliyanie gliprolinov na strukturnofunktsionalnoe sostoyanie slizistoy obolochki zheludka i massy tella krys $v$ usloviyakh dlitelnogo vvedeniya glutamata natriya [Influence of glyprolines on the structural and functional state of the gastric mucosa and body weight of rats under conditions of prolonged administration of sodium glutamate]. Fizika zhivogo Physics of the Living, 18,1, 154-159 [in Russian].

11. Dosvyadchynska, M.R., \&Antoniak, H.L. (2012). Peroksydne okysnennia lipidiv ta aktyvnyst antyoksydantnykh enzymiv u klitynakh lehen shchuriv za shchodobovoho vvedennia aflatoksynu B1 [Lipid peroxidation and activity of antioxidant enzymes in rat lung cells with daily administration of aflatoxin B1]. Biolohiia tvaryn Animal Biology, 14, 1-2, 108-112 [in Ukrainian]. 
12. Dubinina, E.E. (2000). Okislitelnaya modifikatsiya belkov plazmy krovi bolnykh psikhicheskimi rasstroystvami (depresiya, depersonalizatsiya) [Oxidative modification of blood plasma proteins in patients with mental disorders (depression, depersonalization)]. Voprosy meditsinskoy khimii - Issues of Medical Chemistry, 46, 4, 398-409 [in Russian].

13. Lowery, O.H., Rosebroughh, N.I., Farr, A.L., \& Randall, R.I. (1951). Protein measurement with the Folin phenol reagent. J. Biol. Chem., 193 (1), 265-275.

14. Jones, L.A., \& Holmes, R.B. (1956). Spectrophotometric studies of some 2,4-dinitrophenylhydrazones. Analytical Chemistry, 28, 2, 191-198.

15. Shevelkova, A.A., \& Vjushina, A.V. (2012). Okislitelnaya modifikatsiya belkov i soderzhanie tiolov $v$ krovi pri fiziologicheski protekayushchey beremennosti [Oxidative modification of proteins and the content of thiols in the blood during physiological pregnancy]. Zhurnal akusherstva i zhenskikh bolezney - Journal of Obstetrics and Women's Diseases, 1 (4), 109-112 [in Russian].

16. Gubskij, Ju.I. (2005). Toksikologicheskie posledstviya okislitelnoy modifikatsii belkov pri razlichnykh patologicheskikh sostoyaniyakh [Toxicological consequences of oxidative modification of proteins in various pathological conditions]. Sovremennye problemy toksikologii - Modern Problems of Toxicology, 8, 3, 20-27 [in Russian].

17. Dubinina, E.E. (2006). Produkty metabolizma kisloroda $v$ funktsionalnoy aktivnosti kletok (zhizn $i$ smert, sozidanie i razrushenie). Fiziologicheskie i klinikobiohimicheskie aspekty [Oxygen metabolism products in the functional activity of cells (life and death, creation and destruction). Physiological and clinical-biochemical aspects]. St. Petersburg: Meditsinskaya pressa [in Russian].

18. Vedunova, M.V., Sazanov, A.I., Kontorshhikova, K.N. (2010). Vliyanie nizkikh terapevticheskikh doz ozona na uroven okislstelnoy modifikatsii belkov [Effect of low therapeutic ozone doses on the level of oxidative modification of proteins]. Vestnik Nizhegorodskogo universiteta im. N.I. Lobachevskogo - Bulletin of the Nizhny Novgorod University by N.I. Lobachevsky, 2, 504507 [in Russian].

19. Ergin, V., Hariry, R.E., \& Karasu, Ç. (2013). Carbonyl stress in aging process: Role of vitamins and phytochemicals as redox regulators. Aging and Disease, 4, 5, 279-294.

20. Mjalyuk, O.P. (2015). Stan vilnoradykalnoho okysnennia u tkanynakh pechinky eksperymentalnykh shchuriv pry alimentarnomu ozhyrinni [The state of free radical oxidation in the liver tissues of experimental rats in alimentary obesity. Bulletin of problems of biology and medicine]. Visnyk problem biolohii i medytsyny - Bulletin of Problems of Biology and Medicine, 4, 1 (124), 120-123 [in Ukrainian].

21. Krynytska, I., Marushchak, M., Svan, O., Akimova, V., Mazur, L., \& Habor, H. The indices of endogenous intoxication in rats with carrageenan solution consumption. Georgian Medical News (279), 196-200.

22. Krynytska, I., Marushchak, M., \& Rutska, A. (2019). Gender-specific differences of oxidative processes in the population of circulating neutrophils of rats in a setting of prolonged administration of monosodium glutamate. Romanian Journal of Diabetes Nutrition and Metabolic Diseases, 26, 2, 119-127.

23. Zyn, A., Holovchak, N., \& Sanhurskyi, D. (2012). Okysna modyfikatsiia bilkiv u zarodkakh viuna MISGURNUS FOSSILIS L. Uprodovzh embriohezu za dii hipokhlorytu natriiu [Oxidative modification of proteins in embryos of MISGURNUS FOSSILIS L. during embryogenesis under the action of sodium hypochlorite]. Visnyk Lvivskoho universytetu. Seriia biolohichna - Bulletin of Lviv University. Biological Series, 61, 11-19 [in Ukrainian].

24. Marushchak, M. (2013). Rol aktyvnyh form kysniu u rozvytku i prohresuvanni hostroho urazhennia lehen $v$ eksperymenti [The role of reactive oxygen species in the development and progression of acute lung injury in the experiment]. Medychna khimiia - Medical Chemistry, 14, 1, 104-108 [in Ukrainian].

п. И. Бучко, М. И. Марущак

ТЕРНОПОЛЬСКИЙ НАЦИОНАЛЬНЫЙ МЕДИЦИНСКИЙ УНИВЕРСИТЕТ ИМЕНИ И. Я. ГОРБАЧЕВСКОГО МОЗ УКРАИНЫ

\section{ОСОБЕННОСТИ ОКИСЛИТЕЛЬНОЙ МОДИФИКАЦИИ ПРОТЕИНОВ ПРИ КОМБИНИРОВАННОМ ДЕЙСТВИИ ПИЩЕВЫХ ДОБАВОК}

\section{Резюме}

Вступление. Сокращение продолжительности жизни населения Украины, резкое снижение качества жизни и индекса здоровья нации при значительном нарушении пищевого статуса предопределяют необходимость поднятия вопросов относительно качества пищевой продукции, в том числе и неконтролируемого использования пищевых добавок, поэтому данное исследование является актуальным.

Цель исследования - оценить показатели окислительной модификации протеинов в тканях организма крыс при применении растворов к-каррагинана, натрия глутамата и их комбинированном действии.

Методы исследования. Исследование проведено на 48 белых нелинейных крысах-самцах, которых разделили на 4 группы: 1-я - контроль (интактные животные); 2-я - животные, которым внутрижелудочно вводили к-каррагинан в дозе 40 мг/кг в течение 1 месяца; 3-я - животные, которым внутрижелудочно вводили натрия глутамат в дозе 50 мг/ке; 4-я - животные, которым внутрижелудочно вводили к-каррагинан и натрия глутамат в вышеуказанных дозах. Для оценки спонтанной окислительной модифрикации протеинов (ОМП) спектрофотометрически в ультрафриолетовой части спектра на длине волны 370 нм определяли кетондинитрофренилгидразоны нейтрального характера (КДНФГ) и в области видимого света 430 нм - альдегиддинитрофенилгидразоны основного характера (АДНФГ). С целью оценки 
стимулированной ОМП предварительно добавляли к опытной и контрольной пробам по 0,1 мл приготовленных еx tempore $410^{-3} \mathrm{M} \mathrm{FeSO}_{4}, 110^{-3} \mathrm{M}$ ЭДТА, 310-4 $\mathrm{M} \mathrm{H}_{2} \mathrm{O}_{2}$.

Результаты и обсуждение. В сыворотке крови доля первичных (АДНФГ) и вторичных (КДНФГ) маркеров исследовательских групп практически не отличалась от соотношения в контрольной группе. В тканях легких при введении экспериментальным животным натрий глутамата менялось соотношение АДНФГ к КДНФГ в сторону увеличения доли вторичных маркеров окислительного стресса, тогда как в других исследовательских группах их соотношение практически не отличалось от контроля. В тканях печени доля первичных и вторичных маркеров исследовательских групп практически не отличалась от соотношения в контрольной группе. Анализ соотношения первичных и вторичных маркеров ОМПуказывает на увеличение доли маркеров поздней деструкции в тканях легких при применении натрий глутамата. Меньшая доля вторичных маркеров в сыворотке крови при введении к-каррагинана, в отношении группы животных, которым вводили натрий глутамат, может свидетельствовать о более быстрой утилизации измененных протеинов, так называемом вторичном антиоксидантном эфффекте.

Вывод. При комбинированном действии растворов к-каррагинана и натрий глутамата достоверно повышается спонтанная окислительная модификация протеинов относительно контроля и отдельного действия пищевых добавок, что сопровождается истощением резервно-адаптационного потенциала в крови, легких и печени, соответственно, на 33,4, 32,9 и 24,0%.

КЛЮЧЕВЫЕ СЛОВА: пищевые добавки; окислительная модификация протеинов; кровь; печень; легкие; эффект.

P. I. Buchko, M. I. Marushchak

I. HORBACHEVSKY TERNOPIL NATIONAL MEDICAL UNIVERSITY

\section{SPECIFIC FEATURES OF PROTEINS OXIDATIVE MODIFICATION IN THE COMBINED ACTION OF FOOD ADDITIVES}

\section{Summary}

Introduction. A decrease in the life expectancy of the population of Ukraine, a sharp decrease in the quality of life and the health index of the nation with a significant violation of the nutritional status predetermines the need to raise issues of food quality, including the uncontrolled use of food additives, which determines the relevance of this study.

The aim of the study - to evaluate the indicators of oxidative modification of proteins in the tissues of the rat body when using a solution of $\mathrm{K}$-carrageenan, sodium glutamate and their combined action.

Research Methods. The study was carried out on 48 white nonlinear male rats, which were divided into 4 groups: 1 - control (intact animals), 2 - animals that were intragastrically injected with $\mathrm{k}$-carrageenan at a dose of $40 \mathrm{mg} / \mathrm{kg}$ for 1 month, 3 - animals, which intragastrically injected sodium glutamate at a dose of $50 \mathrm{mg} / \mathrm{kg}$ for 1 month, 4 animals that were intragastrically injected with carrageenan and sodium glutamate in the above doses. To assess the spontaneous oxidative modification of proteins (OMP) spectrophotometrically in the ultraviolet part of the spectrum at a wavelength of $370 \mathrm{~nm}$, neutral ketone dinitrophenylhydrazones (CDNPH) and in the visible light region $430 \mathrm{~nm}$, aldehyde dinitrophenylhydrazones of the basic nature (ADNPH) were determined. To assess the stimulated OMP $0.1 \mathrm{ml}$ of prepared ex tempore $410^{-3} \mathrm{M}$ FeSO4, $110^{-3} \mathrm{M}$ EDTA, 310-4 $\mathrm{M} \mathrm{H} 2 \mathrm{O} 2$ was previously added to the experimental and control samples.

Results and Discussion. It was found that the proportion of primary (ADNPH) and secondary (CDNPH) markers in the blood serum did not practically differ from the ratio in the control group. In the lung tissues, when sodium glutamate was administered to experimental animals, the ratio of ADNPG to CDNPG changed towards an increase in the proportion of secondary markers of oxidative stress, while in other study groups their ratio practically did not differ from the control. In liver tissues, the proportion of primary and secondary markers in the experimental groups did not practically differ from the ratio in the control group. Analysis of the ratio of primary and secondary markers of oxidative modification of proteins indicates an increase in markers of late destruction in lung tissues with the use of sodium glutamate. The reduced proportion of secondary markers in the blood serum upon administration of carrageenan in relation to the group of animals that were injected with sodium glutamate may indicate a faster utilization of the altered proteins, the so-called secondary antioxidant effect.

Conclusions. In the combined action of solutions of $k$-carrageenan and sodium glutamate, spontaneous oxidative modification of proteins significantly increases relative to the control and individual action of food additives, which is accompanied by depletion of reserve-adaptive potential in the blood, lungs and liver, respectively, by $33.4 \%$, $32.9 \%$ and $24.0 \%$.

KEY WORDS: food additives; oxidative modification of proteins; blood; liver; lungs; effect.

Адреса для листування: М. І. Марущак, Тернопільський національний медичний університет імені І. Я. Горбачевського мОЗ України, майдан Волі, 1, Тернопіль, 46001, Україна, e-mail: marushchak@tdmu.edu.ua. 